\title{
Oceanic influence on atmospheric mercury at coastal and inland sites: a springtime noreaster in New England
}

\author{
J. M. Sigler, H. Mao, B. C. Sive, and R. Talbot \\ Institute for the Study of Earth, Oceans and Space, Climate Change Research Center, University of New Hampshire, \\ Morse Hall, 8 College Road, Durham, NH 03824-3525, UK
}

Received: 5 February 2009 - Published in Atmos. Chem. Phys. Discuss.: 1 April 2009

Revised: 2 June 2009 - Accepted: 3 June 2009 - Published: 18 June 2009

\begin{abstract}
Continuous measurements of elemental $\left(\mathrm{Hg}^{0}\right)$ and reactive mercury were conducted at two sites in New Hampshire during a powerful April 2007 noreaster. During the most intense period of the storm, enhancements of $\sim 30-50$ ppqv in $\mathrm{Hg}^{0}$ were observed at a coastal and a high elevation inland site. This enhancement occurred simultaneously with elevated mixing ratios of three marine tracers, $\mathrm{CH}_{3} \mathrm{I}, \mathrm{CH}_{2} \mathrm{Br}_{2}$ and $\mathrm{CHBr}_{3}$. These observations suggest a marine source of $\mathrm{Hg}^{0}$, possibly outgassing from the ocean surface during strong turbulence. The $\mathrm{Hg}^{0}$ enhancement observed $100 \mathrm{~km}$ inland suggests that the impact of coastal storms on terrestrial $\mathrm{Hg}$ cycling may not be limited to near-shore environments. Combining $\mathrm{Hg}^{0}$ and marine tracer measurements during the storm with estimates of oceanic tracer fluxes during previous strong storms yields an orderof-magnitude estimate of the oceanic source of $\mathrm{Hg}^{0}$ during the storm $\left(\sim 7 \mathrm{ppqv}^{-1}\right)$ which can account for the observed enhancement at the field sites.
\end{abstract}

\section{Introduction}

Mercury $(\mathrm{Hg})$ has been identified as an important environmental pollutant, yet our understanding of both natural and anthropogenic emissions and environmental cycling of $\mathrm{Hg}$ is very limited. Oceanic emissions are important in the global atmospheric mercury ( $\mathrm{Hg}$ ) budget, possibly accounting for as much as 39\% (Mason and Sheu, 2002) of global emissions. However, estimates of the total oceanic source based on global models as well as sparse measurements indicate large uncertainty, ranging from $4 \mathrm{Mmol} \mathrm{yr}^{-1}$ (Lamborg et al., 2002) to $14.1 \mathrm{Mmol} \mathrm{yr}^{-1}$ (Strode et al., 2007), and our current understanding of seasonal and spatial variability of this marine source is poor.

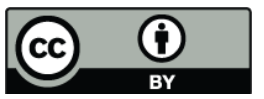

Correspondence to: J. M. Sigler (jsigler@gust.sr.unh.edu.)
Relatively few field studies have examined $\mathrm{Hg}$ dynamics in coastal or purely marine atmospheres, and their results are disparate. Even fewer examined the impact of the ocean as a source of $\mathrm{Hg}^{0}$ using ambient measurements. Observations at coastal stations in Ireland (Ebinghaus et al., 2002; Kock et al., 2007) suggested an influence of oceanic emissions on concentrations of total gaseous mercury (TGM). Measurements in the Mediterranean Sea by Sprovieri et al. (2003) indicated enhanced $\mathrm{Hg}^{0}$ compared to coastal sites (Pirrone et al., 2003) and therefore a net source from oceanic evasion. A recent study by Mao et al. (2008) suggested the ocean was a source of $\mathrm{Hg}^{0}$ by comparing ambient levels of $\mathrm{Hg}^{0}$ with a marine tracer $\left(\mathrm{CHBr}_{3}\right)$ at a coastal site in the northeastern United States.

Several recent studies suggest that the marine boundary layer is not a significant source of RGM at coastal sites in North America (Malcolm et al., 2003; Laurier and Mason, 2007; Engle et al., 2008). Measurements at several Mediterranean Sea coastal sites (Spain, Italy, Turkey and Greece) suggest that on average, RGM comprises $<3 \%$ of TGM, similar to non-oceanic environments, although high RGM episodes at some sites were associated with transport from the ocean, suggesting $\mathrm{Hg}$ evasion from the ocean surface followed by oxidation to RGM (e.g. Pirrone et al., 2003). In contrast, observations of speciated $\mathrm{Hg}$ over open ocean show elevated RGM concentrations (e.g. Sprovieri et al., 2003; Mason et al., 2001; Laurier et al., 2003). It has been speculated that gaseous elemental $\mathrm{Hg}\left(\mathrm{Hg}^{0}\right)$ is oxidized by abundant halogen species, such as bromine $(\mathrm{Br}), \mathrm{BrO}$ and $\mathrm{BrCl}$, to reactive gaseous $\mathrm{Hg}$ compounds in marine environments (Sprovieri et al., 2003; Laurier et al., 2003; Hedgecock and Pirrone, 2004; Hedgecock et al., 2005). Although some recent studies suggest a minimal influence of marine oxidation mechanisms in near-shore or coastal environments (e.g. Engle et al., 2008), measurements of both $\mathrm{Hg}$ species and marine halogen compounds at coastal sites are very rare.

Published by Copernicus Publications on behalf of the European Geosciences Union. 
In the northeastern United States, coastal environments are impacted during wintertime by mid-latitude cyclonic storms, or noreasters, that transport marine air onto the coast and inland. In 2005-2006, these storms impacted northern New England at a rate of nearly one per month. The degree to which such storm systems impact $\mathrm{Hg}$ cycling in coastal and inland environments is essentially unknown. In April of 2007, the mid-Atlantic and northeastern United States experienced a rare and powerful springtime noreaster; the lowest barometric (sea level) pressure recorded was $958 \mathrm{hPa}$, equivalent to that of a moderate category 3 hurricane. During this event, we monitored $\mathrm{Hg}^{0}$ and RGM continuously at two sites in New Hampshire. We document significant enhancements in $\mathrm{Hg}^{0}$ in both coastal and inland atmospheres during peak storm impact, a phenomenon previously unreported. Observations of marine tracers facilitated a better understanding of salient features of the marine source signature. To our knowledge, the combination of $\mathrm{Hg}^{0}$, RGM, marine tracer and meteorological data along with concurrent $\mathrm{Hg}$ measurements at both inland and coastal sites during a major storm is the first data set of its kind and adds considerably to our understanding of coastal $\mathrm{Hg}$ cycling.

\section{Sampling sites and methods}

This study utilizes measurements from two University of New Hampshire AIRMAP sites, Thompson Farm (TF) (43.11 ${ }^{\circ} \mathrm{N},-70.75^{\circ} \mathrm{W}, 24 \mathrm{~m}$ a.g.1.) and Pac Monadnock (PM) $\left(42.86^{\circ} \mathrm{N},-71.88^{\circ} \mathrm{W}, 700 \mathrm{~m}\right.$ a.g.l.). TF, a rural site surrounded by mixed hardwood/pine forest and agricultural fields, is located in Durham, New Hampshire, $5 \mathrm{~km}$ from Great Bay and $\sim 25 \mathrm{~km}$ from the Gulf of Maine. PM is a heavily-forested, high-elevation site $\sim 100 \mathrm{~km}$ inland near Peterborough, New Hampshire. We note that in this study, we also make reference to previous studies conducted at an additional AIRMAP site at Appledore Island (AI), located in the Gulf of Maine $\left(42.97^{\circ} \mathrm{N},-70.62^{\circ} \mathrm{W}\right)$. However, no $\mathrm{Hg}$ (or other) observations were recorded at AI during the study period.

At TF and PM, total gaseous mercury (TGM) is measured via cold vapor atomic florescence spectrophotometry using a $\mathrm{Hg}$ vapor analyzer (model 2537A, Tekran, Inc.) at 5-min intervals with a detection limit of $\sim 5-10 \mathrm{ppqv}$ (1 $\mathrm{ng} \mathrm{Hg} \mathrm{m}^{-3} \sim 112$ ppqv). TGM measurements at $\mathrm{TF}$ and PM have been ongoing since November 2003 and December 2004, respectively, while RGM measurements were added during the winter of 2006-2007.

RGM is measured with a speciation unit (Tekran model 1130) consisting of a denuder and pump module installed upstream of the TGM analyzer. The KCl-coated denuder strips out RGM at a flow rate of $10 \mathrm{~L} \mathrm{~min}^{-1}$ over a 2-h sampling period with a limit of detection of $\sim 0.1$ ppqv, based on three times the standard deviation of the average blank (e.g. $0.003 \pm 0.03$ ppqv, $n=3626$ at TF in 2007). During the sampling interval the 2537A continuously measures $\mathrm{Hg}^{0}$ (we therefore present $\mathrm{Hg}^{0}$ data in this paper, although in or experience, $\mathrm{Hg}^{0}$ comprises $>99 \%$ of TGM at each site; Sigler et al., 2009). To ensure clean operation, the denuders, glassware, impactor frits and filters are replaced on a 10-day basis. Soda lime traps and zero air canisters are changed as necessary. Blank correction is rarely needed as mixing ratios of 0 ppqv were achieved for $>99 \%$ of zero air flushes after desorption and for $>94 \%$ of zero air flushes immediately before desorption at both TF and PM during 2007. Additional details on $\mathrm{Hg}^{0}$ and RGM measurements at each site can be found in Mao et al. (2008) and Sigler et al. (2009).

Air temperature, pressure, relative humidity, wind speed and direction are measured at 1-minute resolution (Davis, Inc.), and marine tracers $\left(\mathrm{CHBr}_{3}, \mathrm{CH}_{2} \mathrm{Br}_{2}\right.$ and $\left.\mathrm{CH}_{3} \mathrm{I}\right)$ are measured at TF with two-hour resolution using a GC system designed for dual-stage trapping without using liquid nitrogen (Sive et al., 2005). Details of these measurements are given in Zhou et al. (2005), Sive et al. (2007) and Zhou et al. (2008). Carbon monoxide (CO) was measured via infrared spectroscopy $(4.6 \mu \mathrm{m})$ at 1 -min resolution with a modified Thermo Environmental Instruments model 48CTL. Calibrations are performed every $6.25 \mathrm{~h}$, and the limit of detection was $\sim 20$ ppbv (further details in Mao and Talbot, 2004).

\section{Results and discussion}

\subsection{Noreaster characteristics}

The April 2007 noreaster developed as a low pressure system over the southwestern United States which tracked toward the east coast and then northward on 15 April. The storm moved to the northeastern US along the coastline, where the low pressure center eventually stalled over the ocean near Long Island, New York, by 00:00 UTC on 16 April, and was stationary until slowly moving eastward out to sea by 00:00 UTC on 17 April (Fig. 1). On 16 April, wind gusts of $>60 \mathrm{~m} \mathrm{~s}^{-1}$ and $>35 \mathrm{~m} \mathrm{~s}^{-1}$, characteristic of a category 1 hurricane, were recorded at the AIRMAP site at Mount Washington, New Hampshire, and along the Maine coast (nbdc.noaa.gov), respectively. The storm reached peak intensity at TF and PM between 00:00 UTC and 14:00 UTC on 16:00 April, as atmospheric pressure reached minimum values of $\sim 980$ and $\sim 900 \mathrm{hPa}$ respectively, and instantaneous wind speeds exceeded $10 \mathrm{~m} \mathrm{~s}^{-1}$ at TF and $15 \mathrm{~m} \mathrm{~s}^{-1}$ at PM (Fig. 2a) with gusts up to $30 \mathrm{~m} \mathrm{~s}^{-1}$. Predominantly east-northeasterly winds at TF and PM from approximately 16:00 UTC on 15 April to 24:00 UTC on 16 April (Fig. 3) suggested continuous onshore flow, and trajectory simulations (NOAA HYSPLIT-4, Draxler and Rolph (2003)) indicated a long oceanic fetch. Precipitation in southern New Hampshire began as light snow mixed with rain, and changed to heavy rain by the evening of 15 April; 7.5 inches of rainfall were recorded in Durham from 15 to 17 April. The storm 


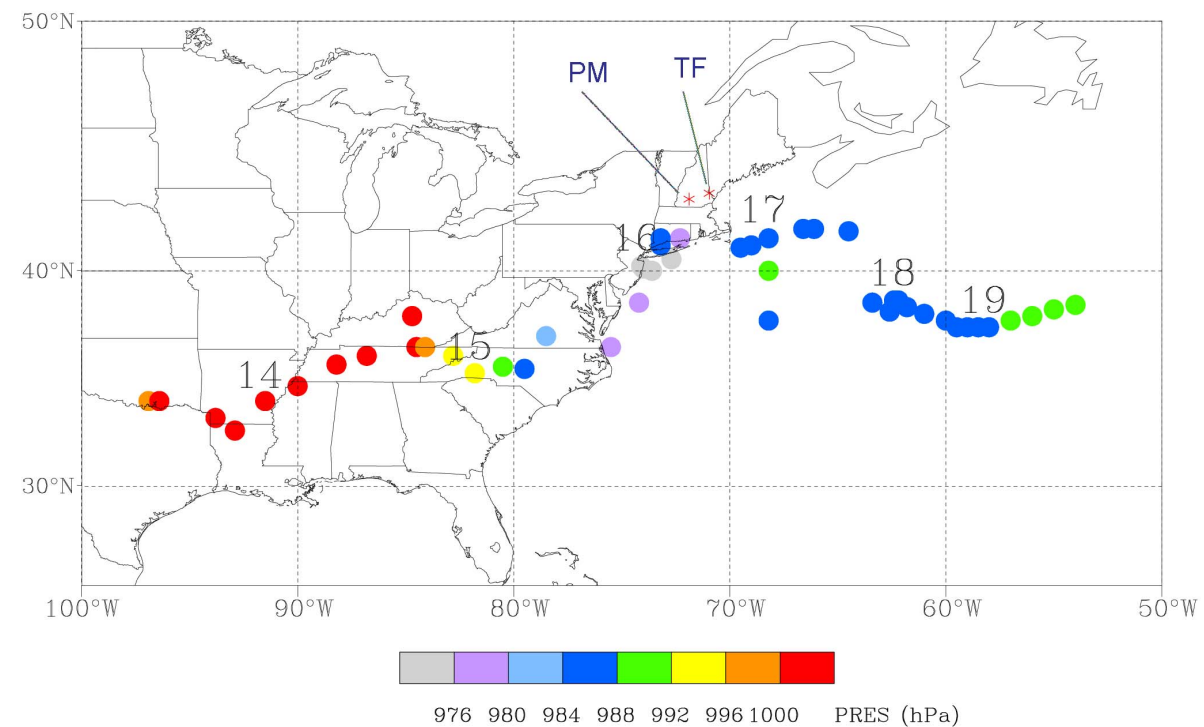

Fig. 1. Storm track of noreaster, 14-19 April 2007. Time labels represent 12:00 UTC on the day of April indicated. Circles represent the low pressure center. The discontinuous storm motion on 17 April was due to the development of a secondary system at the triple point of the original storm and eventually became the primary center. The two systems eventually merged near $40.0^{\circ} \mathrm{N},-68.2^{\circ} \mathrm{W}$ at $00: 00 \mathrm{UTC}$ on 18 April.

subsequently weakened as it moved slowly eastward with winds shifting to north-northeasterly over New England, and conditions at TF and PM remained overcast with occasional light rain through 18 April.

\section{2 $\mathrm{Hg}^{0}$ and $\mathrm{RGM}$ levels during the storm}

During the morning of 16 April, mixing ratios of $\mathrm{Hg}^{0}$ increased from $\sim 175 \mathrm{ppqv}$ to maxima of $227 \mathrm{ppqv}$ and 201 ppqv at TF and PM respectively (Fig. 2b), and peaked approximately when the storm reached its local maximum intensity in wind speed and minimum in atmospheric pressure (Fig. 2a). The enhancement at both sites was statistically significant $(p<0.01)$ relative to all 5-min $\mathrm{Hg}^{0}$ observations during spring of 2007. Enhancements this large are fairly rare at $\mathrm{TF}$, as sustained episodes (1-2 h) of $\mathrm{Hg}^{0}>200$ ppqv were observed approximately once per month during spring/summer of 2007, and $<4 \%$ of all 5 -min observations of $\mathrm{Hg}^{0}$ at $\mathrm{TF}$ in 2007 were $>200$ ppqv. The $\mathrm{Hg}^{0}$ enhancements occurred over a span of $\sim 14 \mathrm{~h}$ at TF and $\sim 10 \mathrm{~h}$ at PM, with mixing ratios increasing to 40-50 ppqv higher than the seasonal mean for 2007 ( $\sim 179$ ppqv) as well as mean springtime values generally observed at TF since 2004 (158-179 ppqv; Mao et al., 2008), and the time series at each site during the storm were well correlated $(r=0.6, p<0.01)$. After this period, $\mathrm{Hg}^{0}$ mixing ratios decreased to pre-storm levels at both sites.

At TF, RGM decreased from typical springtime mixing ratios of $\sim 1.2 \mathrm{ppqv}-$ similar to results from other US coastal sites (Laurier and Mason, 2007) - before the storm to a mean of $\sim 0.3$ ppqv during storm impact (16-18 April; Fig. 2b). Although this is above the limit of detection of the instrumentation ( $\sim 0.1 \mathrm{ppqv})$, the observed decrease in RGM is consistent with the near complete washout of RGM typically observed at TF during rain events (mean of $\sim 0.07$ ppqv in January-September 2007 (Sigler et al., 2009)) owing to the high solubility of $\mathrm{Hg}^{2+}$ and efficient removal from the atmosphere by precipitation. At PM, RGM is scarcely present (mean of 0.17 ppqv in 2007) because of its elevation and distance from major pollution sources. RGM decreased from $\sim 0.7$ ppqv at 10:00 UTC on 15 April to values consistently below detection by 00:00 UTC on 16 April.

\subsection{Oceanic influence}

The significant enhancement of $\mathrm{Hg}^{0}$ at TF and PM occurred on the morning of 16 April, well before its normal daily maximum at TF (Mao et al., 2008; Sigler et al., 2009), which is typically in mid-afternoon coincident with maximum temperature and solar radiation. Precipitation may result in enhanced $\mathrm{Hg}^{0}$ emissions from soil (Lindberg et al., 1999) or perhaps vegetation (Bash and Miller, 2008). Also, negative correlation of ambient TGM and canopy evasion has been observed during wet conditions (Bash and Miller, 2008). However, some studies report enhanced $\mathrm{Hg}$ deposition to wet canopies (Bash and Miller, 2007). In our case study, soil emission as a possible source of the observed $\mathrm{Hg}^{0}$ enhancement cannot be entirely ruled out. Enhanced soil emissions from precipitation may occur over a brief period (12-24h) and during the transition from dry to wet conditions (Lindberg et al., 1999), and in this case, the soil and canopy were saturated after receiving heavy precipitation on 12 April and throughout the day of 15 April. Recent studies suggest that 

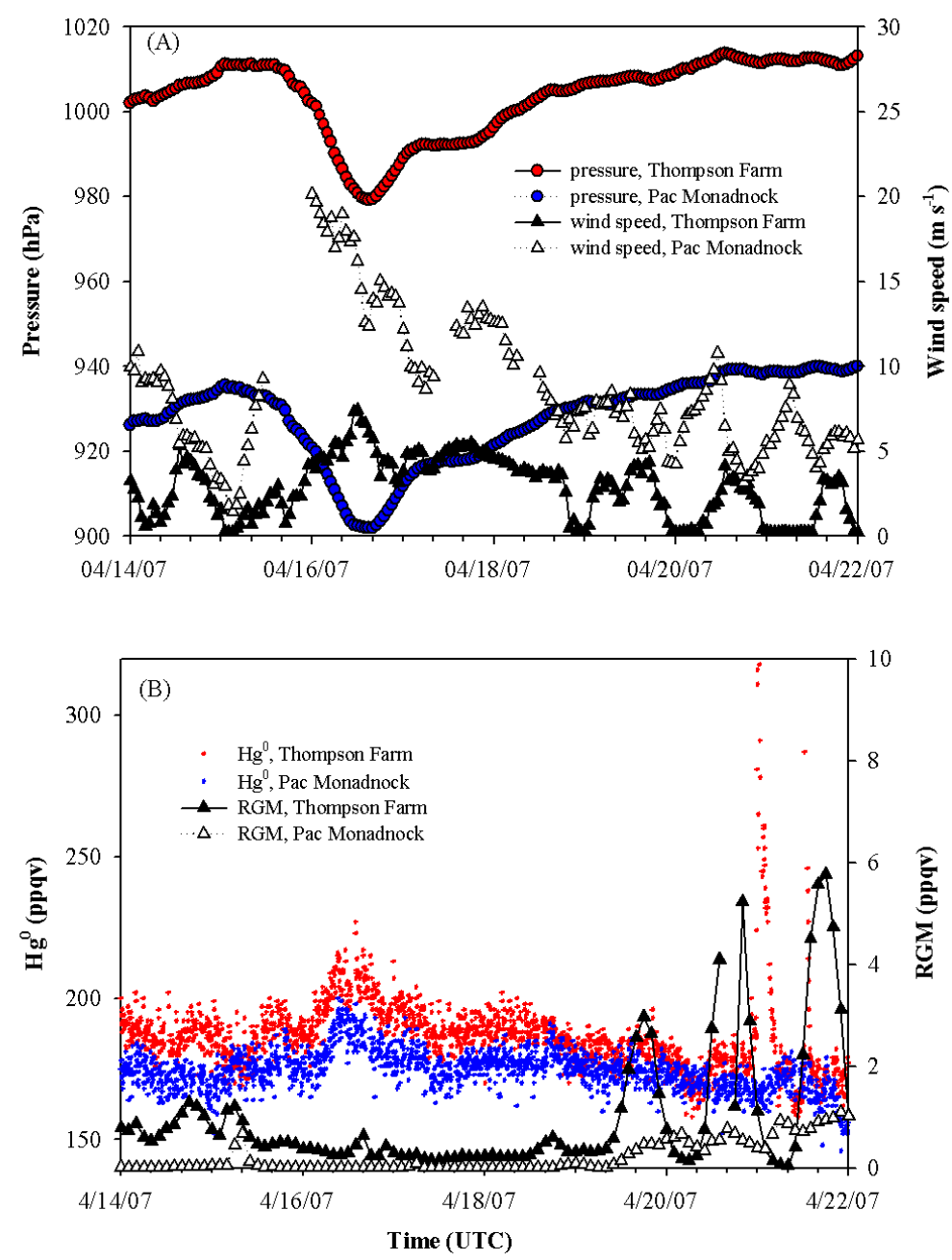

Fig. 2. (a) Time series of wind speed and pressure (hourly averages) and (b) $\mathrm{Hg}^{0}$ (5-min averages) and RGM (2-hour averages) at Thompson Farm and Pac Monadnock, NH, during week of 14 April 2007. Noreaster event is 15-17 April.

enhanced emission can occur for several days if soil water is below field capacity (Gustin and Stamenkovic, 2005). However, measurements during other periods of heavy rain at both sites, even after extended dry periods, indicate that $\mathrm{Hg}^{0}$ rarely increases by $>25$ ppqv or in any systematic fashion (Sigler et al., 2009) as that shown in Fig. 2. Therefore, soil or vegetation emissions were unlikely to have accounted for the large pulse of $\mathrm{Hg}^{0}$ observed simultaneously at PM and $\mathrm{TF}$, coincident with greatest local storm intensity.

To further corroborate the marine influence on inland sites, we examined measurements of marine tracers $\mathrm{CHBr}_{3}, \mathrm{CH}_{3} \mathrm{I}$ and $\mathrm{CH}_{2} \mathrm{Br}_{2}$ (Fig. 4a). During the storm, $\mathrm{CHBr}_{3}$ reached $3.5 \mathrm{pptv}$ at TF, an order of magnitude higher than its pre/poststorm levels (0.2-0.6 pptv), $\mathrm{CH}_{3} \mathrm{I}$ (0.8 pptv) was approximately three-fold higher and $\mathrm{CH}_{2} \mathrm{Br}_{2}$ was $\sim 70 \%$ higher. Predominant oceanic influence inland during $15-16$ April is also demonstrated by the correlation $(r=0.63, p<0.01)$ between $\mathrm{CHBr}_{3}$ and $\mathrm{CH}_{2} \mathrm{Br}_{2}$, which has previously been used as a marker for assessing the extent of marine influences on air masses (Zhou et al., 2005, 2008). The regression slope of 0.13 was identical to the regression slope of these two species measured at the AIRMAP station on Appledore Island (AI) in 2004 (Zhou et al., 2008), and within the range of reported $\mathrm{CHBr}_{3} / \mathrm{CH}_{2} \mathrm{Br}_{2}$ emission ratios at other coastal and oceanic sites (Carpenter et al., 2003), and therefore establishes the presence of marine air at TF as this ratio is representative of fresh, co-located coastal marine emissions of these species (Carpenter et al., 2003; Zhou et al., 2005). There was no correlation between these species post-storm, when TF received non-oceanic north-northwesterly flow from eastern Canada (Fig. 3) and $\mathrm{Hg}^{0}$ declined to pre-storm levels. We note that $\mathrm{CH}_{3} \mathrm{I}$ was also somewhat positively correlated with $\mathrm{CHBr}_{3}$ ( $r=0.49)$ and $\mathrm{CH}_{2} \mathrm{Br}_{2}$ ( $r=0.43$ ) during the storm period (not shown), but the correlation was only significant at $p<0.05$ for $\mathrm{CH}_{3} \mathrm{I} / \mathrm{CHBr}_{3}$ and at $0.1>p>0.05$ for $\mathrm{CH}_{3} \mathrm{I} / \mathrm{CH}_{2} \mathrm{Br}_{2}$. This may result in part due to the different lifetimes of $\mathrm{CH}_{3} \mathrm{I}$ 


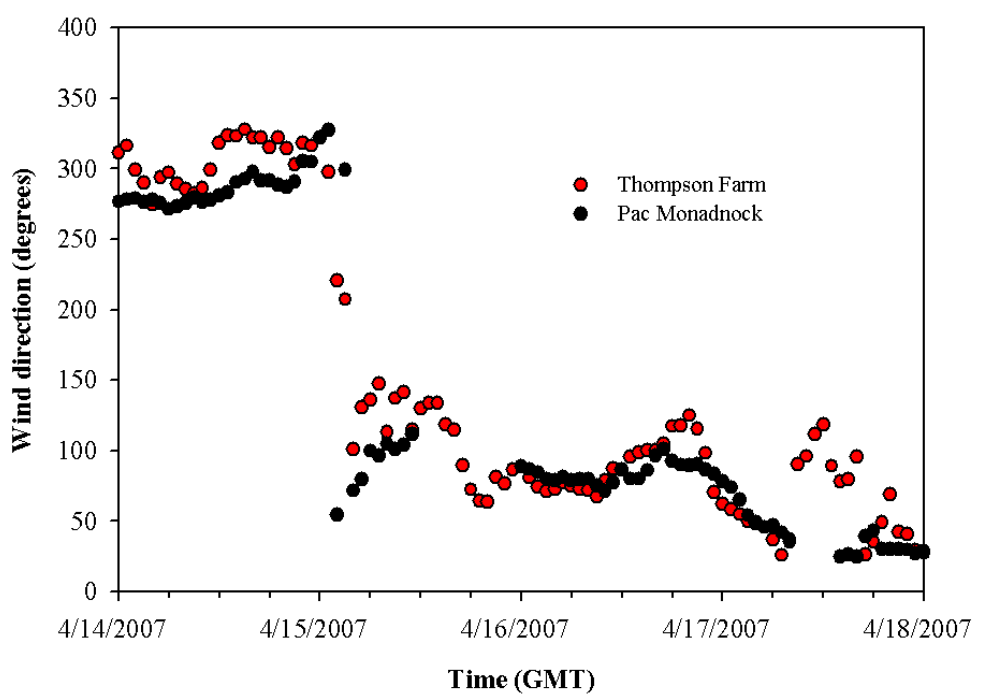

Fig. 3. Time series of wind direction at TF, PM during nor'easter. Data are hourly averages (missing data at PM on 15 April were due to instrument failure).

( $\sim 4$ days), $\mathrm{CH}_{2} \mathrm{Br}_{2}$ (3-4 months) and $\mathrm{CHBr}_{3}$ (2 weeks) and the variability in their surface seawater concentration (Zhou et al., 2005; Butler et al., 2007). Also, these correlations include data for the entire period during which TF was influenced by marine air (roughly 15 April through the end of 16 April). The correlations become stronger $(r=0.63$, $p<0.01$ for $\mathrm{CH}_{3} \mathrm{I} / \mathrm{CHBr}_{3} ; r=0.8, p<0.01$ for $\left.\mathrm{CH}_{3} \mathrm{I} / \mathrm{CH}_{2} \mathrm{Br}_{2}\right)$ when focused on the period of 15 April to $\sim 13: 00$ UTC on 16 April, when wind speed at TF began to diminish after the peak storm impact (Fig. 2a).

Observations in Figs. 2 and 4 further indicate that the significant enhancements of $\mathrm{Hg}^{0}$ inland during the storm were associated with the influx of marine air. Terrestrial emissions of $\mathrm{CH}_{3} \mathrm{I}$ are known to be reduced under conditions of heavy precipitation (Sive et al., 2007), yet $\mathrm{CH}_{3}$ I was elevated at TF along with $\mathrm{Hg}^{0}$ during the storm, which further rules out a terrestrial source for both species. Also, the ratio of $\mathrm{CH}_{3} \mathrm{I} /$ $\mathrm{CHBr}_{3}$ during the storm period $(\sim 0.16)$ was similar to marine ratios $(\sim 0.13)$ measured in the Gulf of Maine (Zhou et al., 2005). In comparison, inland $\mathrm{CH}_{3} \mathrm{I} / \mathrm{CHBr}_{3}$ ratios corresponding to terrestrial sources at $\mathrm{TF}$ are 3 -fold greater $(>0.3)$ on average (Zhou et al., 2005). Because the storm traveled along the coast en route to New England, it potentially could have entrained anthropogenic emissions from the northeastern urban corridor. However, carbon monoxide (CO), generally a tracer of anthropogenic pollution and well-correlated with $\mathrm{Hg}^{0}$ at TF and PM (Mao et al., 2008), was poorly correlated with $\mathrm{Hg}^{0}$ during the storm period. The time series of $\mathrm{CO}$ during the storm period (not shown) indicates that it was both suppressed and uniform regionally, suggesting that TF and PM were influenced by air with similar characteristics. CO levels during the storm $(\sim 160 \mathrm{ppbv})$ were close to the regional background level ( $\sim 165$ ppbv; Mao et al., 2008), indicative of marine air with minimal anthropogenic influence, i.e. photochemically aged marine air.

Correlation of $\mathrm{Hg}^{0}$ and marine tracers at $\mathrm{TF}$ is rarely observed, as TF is constantly influenced by a multitude of anthropogenic and natural sources, relative changes in $\mathrm{Hg}^{0}$ are small compared to its typical ambient level, and the measurement resolution of tracer species may not be sufficient to capture short-lived events (Mao et al., 2008). However, during the noreaster the $\mathrm{Hg}^{0}$ time series was strongly correlated ( $r=0.8, p<0.01$ ) with $\mathrm{CH}_{3} \mathrm{I}$ (Fig. 4b), weakly with $\mathrm{CH}_{2} \mathrm{Br}_{2}$ $(r=0.36, p<0.1)$, and not correlated with enhanced $\mathrm{CHBr}_{3}$ $(r=0.06, p>0.1)$. The inconsistent tracking of $\mathrm{Hg}^{0}$ among the tracers was borne out by their different temporal variability during the storm. Marine tracers commonly are not correlated geographically in the atmosphere due to different sources in the ocean (Blake et al., 2001). Also, a gradient in $\mathrm{CHBr}_{3}$ and $\mathrm{CH}_{2} \mathrm{Br}_{2}$ mixing ratios exists from ocean to land compared to similar levels of $\mathrm{CH}_{3} \mathrm{I}$ and $\mathrm{Hg}^{0}$ in both environments (Sive et al., 2007; Mao et al., 2008). Thus, compared to $\mathrm{CH}_{3} \mathrm{I}$, inland levels of $\mathrm{CHBr}_{3}$ and $\mathrm{CH}_{2} \mathrm{Br}_{2}$ are more sensitive to marine influence, leading to faster response via earlier occurrence of increases in their mixing ratios. Given these variabilities among $\mathrm{Hg}^{0}$ and marine tracer species, the observed correlations during the storm, even where weak, are highly unusual at TF and likely indicate a common, marine source during the storm.

\subsection{Evasion of $\mathrm{Hg}^{0}$ from sea surface}

Measurements of $\mathrm{Hg}^{0}$ at $\mathrm{AI}$ in summer 2007 showed that mean $\mathrm{Hg}^{0}$ mixing ratios over the Gulf of Maine are comparable to those at TF (Sigler et al., 2009). A possible mechanism for enhanced $\mathrm{Hg}^{0}$ over the ocean during the 

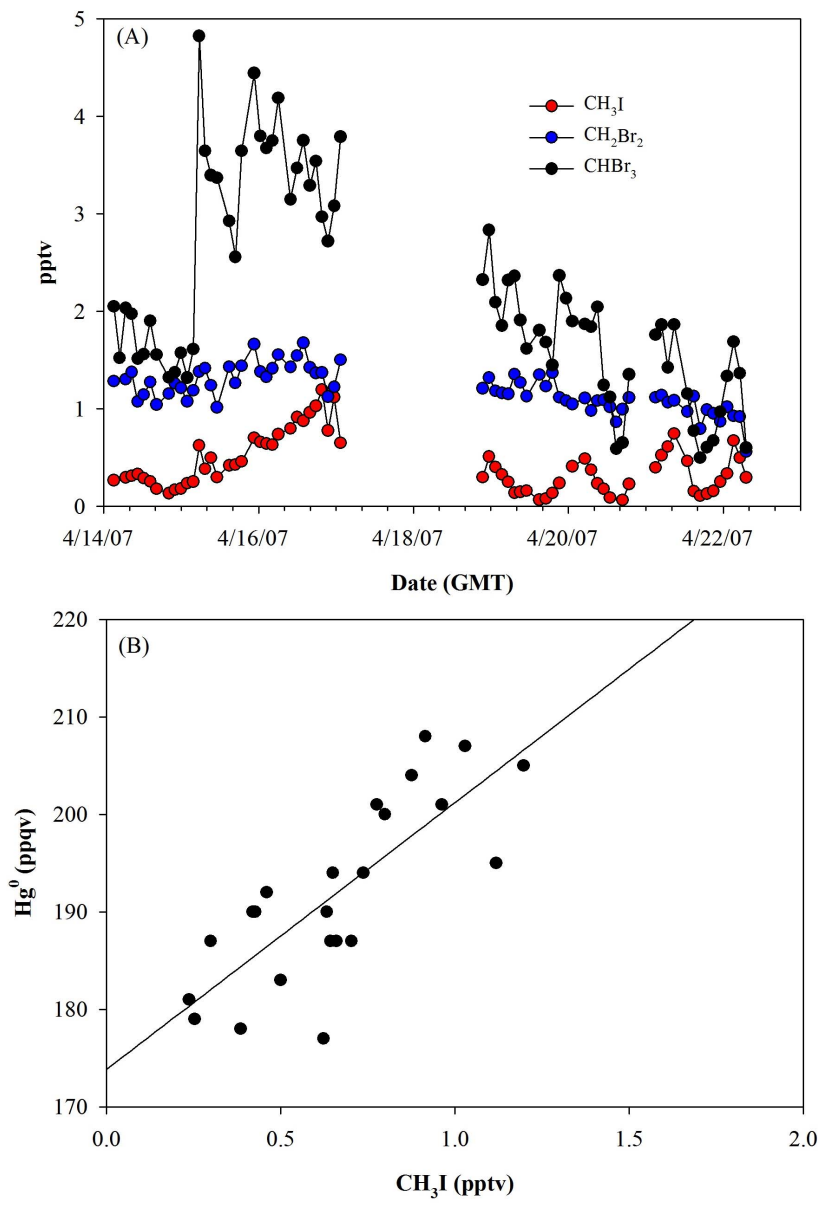

Fig. 4. (a) Time series of marine tracers (2-h averages) at Thompson Farm during week of 14 April 2007. Noreaster event is 15-17 April. The gap in marine tracer data was due to a storm-related power outage. (b) Correlation between $\mathrm{Hg}^{0}$ and $\mathrm{CH}_{3} \mathrm{I}(r=0.8, p<0.01)$, 15-16 April 2007, at Thompson Farm. Data are two-hour averages.

storm may be outgassing from surface waters related to enhanced turbulence. Laurier et al. (2003) proposed a similar mechanism for evasion of dissolved gaseous $\mathrm{Hg}$ from sea water. This hypothesis is supported by measurements at $\mathrm{AI}$ which indicated that $\mathrm{CHBr}_{3}$ and $\mathrm{CH}_{2} \mathrm{Br}_{2}$ increase in the overlying atmosphere as a function of wind speed (Zhou et al., 2008).

A goal of ongoing $\mathrm{Hg}^{0}$ measurements at Appledore is to quantify its oceanic source. The ratio of $\mathrm{Hg}^{0}$ and marine tracers during the storm allows for a rough calculation of the oceanic source strength. Ideally, we would use the $\mathrm{Hg}^{0} / \mathrm{CH}_{3} \mathrm{I}$ ratio since the correlation was strong (Fig. 4b). Unfortunately, this requires an estimate of an oceanic emission rate of $\mathrm{CH}_{3} \mathrm{I}$ during a storm, which to our knowledge has not been previously measured. However, the $\mathrm{CH}_{2} \mathrm{Br}_{2}$ oceanic emission rate during a strong tropical storm was estimated at $\mathrm{AI}$ in 2005 (Zhou et al., 2008) assuming a boundary layer height of $500 \mathrm{~m}$ and using diffusivity parameterizations after Wanninkhof (1992). Using this estimate, we combined the ratio of $\mathrm{Hg}^{0}$ and $\mathrm{CH}_{2} \mathrm{Br}_{2}$ during the noreaster (19.6 ppqv/pptv, based on data obtained from 15 April through the end of 16 April when winds at TF were easterly) with a storm flux of $\mathrm{CH}_{2} \mathrm{Br}_{2}$ at $\mathrm{AI}\left(9.1 \pm 3.1 \mathrm{nmol} \mathrm{m}^{-2} \mathrm{hr}^{-1}\right)$ to obtain a $\mathrm{Hg}^{0}$ emission rate of $\sim 0.15 \pm 0.05 \mathrm{nmol} \mathrm{m}^{-2} \mathrm{hr}^{-1}$, or, assuming a boundary layer depth of $500 \mathrm{~m}, \sim 7 \mathrm{ppqv} \mathrm{hr}^{-1}$. Although there are few measurements of $\mathrm{Hg}$ emission from seawater, we note that this emission rate is significantly higher than average $\mathrm{Hg}^{0}$ fluxes estimated at other oceanic sites (e.g. $0.04 \mathrm{nmol} \mathrm{m}^{-2} \mathrm{hr}^{-1}$ (maximum) at a coastal site in Sweden (Gårdfelt et al., 2001); $\sim 0.01 \mathrm{nmol} \mathrm{m}^{-2} \mathrm{hr}^{-1}$ in the Baltic (Kuss and Schneider, 2007), coastal Ireland (Gårdfelt et al., 2003) and various locations in the Mediterranean Sea (Ferrara et al., 2000; Gårdfelt et al., 2003; Anderrson et al., 2007); $\sim 0.015 \mathrm{nmol}^{-2} \mathrm{hr}^{-1}$ in Long Island Sound, Rolfhus and Fitzgerald (2004); $0.08 \pm 0.05 \mathrm{nmol}^{-2} \mathrm{hr}^{-1}$ in the north Atlantic (Mason et al., 1998)).

We stress that our flux estimate is highly uncertain, for several important reasons. It assumes a boundary layer depth and applies fluxes determined during storms from different seasons and years. Also, the correlation of $\mathrm{Hg}^{0}$ with $\mathrm{CH}_{2} \mathrm{Br}_{2}$ $(r=0.36, p<0.1)$ is weak compared to the other halogen compounds. Moreover, an ideal flux measurement would require instantaneous measurements of the halogen compounds in seawater and in air over the ocean in addition to wind speed observations (e.g. Zhou et al., 2008), which were not available during the storm event. Therefore, the diffusivities or transfer gradients of both $\mathrm{Hg}^{0}$ and the tracer species cannot be evaluated. However, ocean water is often supersaturated with these species (e.g. Gårdfeldt et al., 2001; Zhou et al., 2008), and although there are no direct measurements of $\mathrm{Hg}$ over the ocean during the storm, it has been speculated that $\mathrm{Hg}^{0}$ behaves similarly (e.g. Laurier et al., 2003). Therefore, despite the high uncertainty, this tracer-based flux estimate is useful for $\mathrm{Hg}$, and more importantly, our first-order flux estimate seems to reasonably account for the observed $>50 \mathrm{ppqv}$ $\mathrm{Hg}^{0}$ increase at TF during the storm.

RGM at TF was suppressed during the storm (Fig. 2), reflecting removal by rainfall and suggesting that the marine boundary layer was not a significant source of RGM during the storm. However, RGM observations during this storm are striking in the sense that RGM was typically not detected at TF during rain events in 2007. RGM was detectable, even though at reduced levels, during the noreaster (mean of 0.36 ppqv on 16 April). Marine halogens are thought to play a role in $\mathrm{Hg}^{0}$ chemistry at TF (Mao et al., 2008). Enhanced halogens derived from oceanic outgassing may have played a role in RGM chemistry at TF during the storm, but the exact source of the RGM is currently unknown and the scientific community lacks a firm understanding of RGM production in the presence of marine halogens (e.g. Hedgecock et al., 2005). This is an additional goal of ongoing research at $\mathrm{TF}$ and AI.

The degree to which marine and coastal processes impact the biogeochemical cycling of $\mathrm{Hg}$ in continental settings is 
unknown. Recent evidence suggests that scavenging of $\mathrm{Hg}$ during convective storms is an important source of $\mathrm{Hg}$ in wet deposition in some coastal areas (e.g. southern Florida, United States; Guentzel et al., 2001). Deposition of Hg, and therefore input to terrestrial ecosystems, may be enhanced in areas subject to significant marine influence, even where anthropogenic emissions are lower than other regions (e.g. southeastern United States). Similarly, modeling studies have suggested that elevated RGM over the Atlantic Ocean and Caribbean Sea may contribute to higher deposition in coastal areas in the southeastern U.S. even though anthropogenic emissions are higher in the northeast (Sillman et al., 2007; National Atmospheric Deposition Program, Mercury Deposition Network, http://nadp.sws.uiuc.edu/mdn/). The results of this study raise the possibility of an additional mechanism which may contribute to the $\mathrm{Hg}^{0}$ budget, and possibly to ecosystem input, in coastal environments via direct transport from outgassing during strong maritime storms. This becomes an especially interesting possibility in regions such as the northeastern U. S., which have frequent impact from noreaster-type storm systems.

Measurements at AI in summer 2005 showed weak correlation $(r=0.08, p>0.1)$ between $\mathrm{Hg}^{0}$ mixing ratios there and at PM. The $\mathrm{Hg}^{0}$ enhancement observed at PM during the noreaster is notable because it is an inland, high-elevation site, where marine sources are not expected to have a strong influence. The impact of strong marine storms on terrestrial $\mathrm{Hg}$ cycling may therefore have larger scale impacts than simply coastal environments. Additional measurements of both gaseous and wet-deposited $\mathrm{Hg}$ at coastal and marine sites during storms are needed to better understand their role in Hg cycling.

Acknowledgements. Financial support for this study was provided through the Office of Oceanic and Atmospheric Research of the National Oceanic and Atmospheric Administration under AIRMAP grant \# NA06OAR4600189 to UNH. J. Hegarty provided help with Fig. 1. We thank K. Carpenter, C. Parker, P. Kelly, S. Whitlow, and K. Garrison for contributions to mercury measurements and management of the AIRMAP database.

Edited by: R. Ebinghaus

\section{References}

Andersson, M., Gårdfeldt, K., Wängberg, I., Sprovieri, F., Pirrone, N., and Lindqvist, O.: Seasonal and daily variation of mercury evasion at coastal and off shore sites from the Mediterranean Sea, Mar. Chem., 104, 214-216, 2007.

Bash, J. O. and Miller, D. R.: A relaxed eddy accumulation system for measuring surface fluxes of total gaseous mercury, J. Atmos. Ocean. Tech., 25, 244-257, 2008.

Blake, N. J., Blake, D. R., Simpson, I. J., Lopez, J. P., Johnston, N. A. C., Swanson, A. L., Katzenstein, A. S., Meinardi, S., Sive, B. C., Colman, J. J., Atlas, E., Flocke, F., Vay, S. A., Avery, M. A., and Rowland, F. S.: Large-scale latitudinal and vertical distributions of NMHCs and selected halocarbons in the troposphere over the Pacific Ocean during the March-April 1999 Pacific Exploratory Mission (PEM-Tropics B), J. Geophys. Res., 106(D23), 32627-32644, 2001.

Butler, J. H., King, D. B., Lobert, J. M., Montzka, S. A., YvonLewis, S. A., Hall, B. D., Warwick, N. J., Mondeel, D. J., Aydin, M., and Elkins, J. W.: Oceanic distributions and emissions of short-lived halocarbons, Global Biogeochem. Cy., 21, GB1023, doi:10.1029/2006GB002732, 2007.

Carpenter, L. J., Liss, P. S., and Penkett, S. A.: Marine organohalogens in the atmosphere over the Atlantic and Southern Oceans, J. Geophys. Res., 108, 4256, doi:10.1029/2002JD002769, 2003.

Draxler, R. R. and Rolph, G. D.: HYSPLIT (HYbrid Single-Particle Lagrangian Integrated Trajectory) Model access via http://www. arl.noaa.gov/ready/hysplit4.html, last access in 2008, NOAA Air Resources Laboratory, Silver Spring, MD, 2003.

Ebinghaus, R., Kock, H. H., Coggins, A. M., Spain, T. G., Jennings, S. G., and Temme, C.: Long-term measurements of atmospheric mercury concentrations at Mace Head, Irish west coast, between 1995 and 2001, Atmos. Environ., 36, 5267-5276, 2002.

Engle, M. A., Tate, M. T., Krabbenhoft, D. P., Kolker, A., Olson, M. L., Edgerton, E. S., DeWild, J. F., and McPherson, A. K.: Characterization and cycling of atmospheric mercury along the central US Gulf Coast, Appl. Geochem., 23, 419-437, 2008.

Ferrara, R., Mazzolai, B., Lanzillotta, E., Nucaro, E., and Pirrone, N.: Temporal trends in gaseous mercury evasion from the Mediterranean seawaters, Sci. Total Env., 259, 183-190, 2000.

Gårdfeldt, K., Sommar, J., Ferrara, R., Ceccarini, C., Lanzillotta, E., Munthe, J., Wängberg, I., Lindqvist, O., Pirrone, N., Sprovieri, F., Pesenti, E., and Strömberg, D.: Evasion of mercury from coastal and open waters of the Atlantic Ocean and the Mediterranean Sea, Atmos. Environ., 37(S1), 73-84, 2003.

Guentzel, J. L., Landing, W. M., Gill, G. A., and Pollman, C. D.: Processes influencing rainfall deposition of mercury in Florida, Environ. Sci. Technol., 35, 863-873, 2001.

Gustin, M. S. and Stamenkovic, L.: Effect of watering and soil moisture on mercury emissions from soils, Biogeochemistry, 76, 215-232, 2005.

Hedgecock, I. M. and Pirrone, N.: Chasing quicksilver: Modeling the atmospheric lifetime of $\mathrm{Hg}^{0}(\mathrm{~g})$ in the marine boundary layer at various latitudes, Environ. Sci. Technol., 38, 69-76, 2004.

Hedgecock, I. M., Trunfio, G. A., Pirrone, N., and Sprovieri, F.: Mercury chemistry in the MBL: Mediterranean case and sensitivity studies using the AMCOTS (Atmospheric Mercury Chemistry over the Sea) model, Atmos. Environ., 39, 7217-7230, 2005.

Kock, H. H., Beiber, E., Ebinghaus, R., Spain, T. G., and Thees, B.: Comparison of long-term trends and seasonal variations of atmospheric mercury concentrations at the two European coastal monitoring stations Mace Head, Ireland and Zingst, Germany, Atmos. Environ., 39, 7549-7556, 2005.

Kuss, J. and Schneider, B.: Variability of the gaseous elemental mercury sea-air flux of the Baltic Sea, Environ. Sci. Technol., 41, 8018-8023, 2007.

Lamborg, C. H., Fitzgerald, W. F., O’Donnell, J., and Torgeson, T.: A non-steady state compartmental model of global-scale mercury biogeochemistry with interhemispheric atmospheric gradients, Geochim. Cosmochim. Ac., 66, 1105-1118, 2002.

Laurier, F. J. G., Mason, R. P., Whalin, L., and Kato, S.: Reactive 
gaseous mercury formation in the North Pacific Ocean's marine boundary layer: A potential role of halogen chemistry, J. Geophys. Res., 108(D17), 4529, doi:10.1029/2003JD003625, 2003.

Laurier, F. and Mason, R.: Mercury concentration and speciation in the coastal and open ocean boundary layer, J. Geophys. Res., 112, D06302, doi:10.1029/2006JD007320, 2007.

Lindberg, S. E., Zhang, H., Gustin, M., Vette, A., Marsik, F., Owens, J., Casimir, A., Ebinghaus, R., Edwards, G., Fitzgerald, C., Kemp, J., Kock, H. H., London, J., Majewski, M., Poissant, L., Pilote, M., Rasmussen, P., Schaedlich, F., Schneeberger, D., Sommar, J., Turner, R., Wallschläger, D., and Xiao, Z.: Increases in mercury emission from desert soils in response to rainfall and irrigation, J. Geophys. Res., 104(D17), 21879-21888, 1999.

Malcolm, E. G., Keeler, G. J., and Landis, M. S.: The effects of the coastal environment on the atmospheric mercury cycle, J. Geophys. Res., 108, 4357, doi:10.1029/2002JD003084, 2003.

Mao, H. and Talbot, R.: $\mathrm{O}_{3}$ and $\mathrm{CO}$ in New England: Temporal variation and relationships, J. Geophys. Res., 109, D21304, doi:10.1029/2004JD004913, 2004.

Mao, H., Talbot, R. W., Sigler, J. M., Sive, B. C., and Hegarty, J. D.: Seasonal and diurnal variations of $\mathrm{Hg}$ over New England, Atmos. Chem. Phys., 8, 1403-1421, 2008, http://www.atmos-chem-phys.net/8/1403/2008/.

Mason, R. P., Rohlfus, K. R., and Fitzgerald, W. F.: Mercury in the North Atlantic, Mar. Chem., 61, 37-53, 1998.

Mason, R. P., Lawson, N. M., and Sheu, G.-R.: Mercury in the Atlantic Ocean: factors controlling air-sea exchange of mercury and its distribution in the upper waters, Deep-Sea Res. II, 48, 2829-2853, 2001.

Mason, R. P. and Sheu, G.-R.: Role of the ocean in the global mercury cycle, Global Biogeochem. Cy., 16(4), 1093, doi:10.1029/2001GB001440, 2002.

Pirrone, N., Ferrara, R., Hedgecock, I. M., Kallos, G., Mamane, Y., Munthe, J., Pacyna, J. M., Pytharoulis, I., Sprovieri, F., Voudouri, A., and Wangberg, I.: Dynamic processes of mercury over the Mediterranean region: results from the Mediterranean Atmospheric Mercury Cycle System (MAMCS) project, Atmos. Environ., 37(S1), 21-39, 2003
Rolfhus, K. R. and Fitzgerald, W. F.: Mechanisms and temporal variability of dissolved gaseous mercury production in coastal seawater, Mar. Chem., 90, 125-136, 2004.

Sigler, J. M., Mao, H., and Talbot, R.: Gaseous elemental and reactive mercury in southern New Hampshire, Atmos. Chem. Phys., 9, 1929-1942, 2009, http://www.atmos-chem-phys.net/9/1929/2009/.

Sillman, S., Marsik, F. J., Al-Wali, K. I., Keeler, G. J., and Landis, M. S.: Reactive mercury in the troposphere: Model formation and results for Florida, the northeastern United States, and the Atlantic Ocean, J. Geophys. Res., 112, D23305, doi:10.1029/2006JD008227, 2007.

Sive, B. C., Varner, R. K., Mao, H., Blake, D. R., Wingenter, O. W., and Talbot, R.: A large terrestrial source of methyl iodide, J. Geophys. Res., 34, L17808, doi:10.1029/2007GL030528, 2007.

Sprovieri, F., Pirrone, N., Gårdfeldt, K., and Sommar, J.: Mercury speciation in the marine boundary layer along a $6000 \mathrm{~km}$ cruise path around the Mediterranean Sea, Atmos. Environ., 37(S1), 63-71, 2003.

Strode, S. A., Jaegle, L., Selin, N. E., Jacob, D. J., Park, R. J., Yantosca, R. M., Mason, R. P., and Slemr, F.: Air-sea exchange in the global mercury cycle, Global Biogeochem. Cy., 21, GB1017, doi:10.1029/2006GB002766, 2007.

Wanninkhof, R.: Relationship between wind speed and gas exchange over the ocean, J. Geophys. Res., 97, 7373-7382, 1992.

Zhou, Y., Varner, R. K., Russo, R. S., Wingenter, O. W., Haase, K. B., Talbot, R., and Sive, B. C.: Coastal water source of short-lived halocarbons in New England, J. Geophys. Res., 110, D21302, doi:10.1029/2004JD005603, 2005.

Zhou, Y., Mao, H., Russo, R. S., Blake, D. R., Wingenter, O. W., Haase, K. B., Ambrose, J., Varner, R. K., Talbot, R., and Sive, B. C.: Bromoform and dibromomethane measurements in the seacoast region of New Hampshire, 2002-2004, J. Geophys. Res., 113, D08305, doi:10.1029/2007JD009103, 2008. 